\title{
The importance of always bearing in mind students' privacy, consent, vulnerability, and agency issues
}

\author{
Gloria Natividad Beltrán del Río
}

Published online: 2 February 2021

(c) Association for Educational Communications and Technology 2021

Data gathered by schools have been used in different ways: from formative and summative assessments; from standardized test scores; from cumulative files; data have been used to understand where students are and where they need to go next, as well as to find helpful conducts to adjust the learning and the support offered to the learners so they can succeed (Davis and Heller 2017). Virtual teaching and learning have become the primary means of education during this 2020 world crisis, triggering new kinds of "ethical concerns about the collection and harvesting of student data" (Willis et al. 2016, p. 881).

Willis et al. (2016) provide a heuristic typology as a starting point for discussion about the policy frameworks and processes of ethical review, after analyzing three higher education institutions from three different continents: University of South Africa; Open University, United Kingdom; and Indiana University, United States. The authors summarized four common ethical issues: (1) using the invasive techniques that could direct students to participate in other activities; (2) surveilling students' activities; (3) conducting questionable interventions; and (4) storing and interpreting data for different purposes, with the goal to determine the ethical intersection of internal student data usage and application.

Four scholars volunteered to write a response to Willis et al.'s (2016) research article, focusing their papers on the perspectives of K-12 educational environment, practice K-12, ethical, and policy, as summarized in the following table. All respondents offer valid and important applications of Willis et al.'s study for ethical learning analytics to mitigate harm to students and suggest interesting future efforts on formulating the best ethical practices in this field.

Gloria Natividad Beltrán del Río

gloria.natividad@itsaltillo.edu.mx

1 Tecnológico Nacional de México. Instituto Tecnológico de Saltillo, Blvd. Venustiano Carranza, 25280 Saltillo, Coahuila, Mexico 


\begin{tabular}{|c|c|c|c|}
\hline Respondents & Title & Perspective & $\begin{array}{l}\text { Willis et al. (2016) heuristic } \\
\text { typology of ethical approaches } \\
\text { Value/impact }\end{array}$ \\
\hline Andrea Beerwinkle & $\begin{array}{l}\text { The Use of Learning Analyt- } \\
\text { ics and the Potential Risk of } \\
\text { Harm for K-12 Students Par- } \\
\text { ticipating in Digital Learning } \\
\text { Environments }\end{array}$ & $\begin{array}{l}\text { K-12 Educa- } \\
\text { tional Envi- } \\
\text { ronment }\end{array}$ & $\begin{array}{l}\text { K-12 educational institutions } \\
\text { can utilize the manuscript as a } \\
\text { starting place for review of their } \\
\text { ethical oversights when analyz- } \\
\text { ing student data as more schools } \\
\text { are shifting to digital }\end{array}$ \\
\hline Marie heath & $\begin{array}{l}\text { Buried Treasure or Ill-Gotten } \\
\text { Spoils: The Ethics of Data } \\
\text { Mining and Learning Analyt- } \\
\text { ics in Online Instruction }\end{array}$ & Practice K-12 & $\begin{array}{l}\text { Educational researchers would } \\
\text { find it constructive to revisit } \\
\text { Willis et al.'s (2016) reflections } \\
\text { on data collection, data mining, } \\
\text { and learning analytics when } \\
\text { investigating the large amounts } \\
\text { of virtual data available from } \\
\text { virtual schooling }\end{array}$ \\
\hline Thomas D. Parsons & $\begin{array}{l}\text { Ethics and Educational Tech- } \\
\text { nologies }\end{array}$ & Ethical & $\begin{array}{l}\text { Their approach moves beyond } \\
\text { conceptions of learning analyt- } \\
\text { ics in terms of specific sets of } \\
\text { technologies or innovations } \\
\text { to a "Learning Analytics As" } \\
\text { approach, which makes way for } \\
\text { extant and emerging descriptors } \\
\text { for processes and procedures }\end{array}$ \\
\hline Wenting Weng & $\begin{array}{l}\text { Exploring the Ethical Topic of } \\
\text { Learning Analytics }\end{array}$ & Policy & $\begin{array}{l}\text { Their typology of learning } \\
\text { analytics can give a multi-angle } \\
\text { insight to the related stakehold- } \\
\text { ers, such as researchers in this } \\
\text { field and IRB's reviewers }\end{array}$ \\
\hline
\end{tabular}

According to Klose et al. (2020), it does not seem likely that legislation related to educational-data privacy in different countries will be harmonized in the near future; however, they emphasize that "being aware of and vigilant against all possible risks will protect the interests of the EDM (Educational Data Mining) research's most important stakeholders: learners, students, and teachers" (p. 457).

\section{References}

Davis, M., \& Heller, B. (2017). Raising more than test scores: Does attending a "no excuses" charter high school help students succeed in college? Education Next, 17(1), 64-71.

Klose, M., Desai, V., Song, Y., \& Gehringer, E. (2020). EDM and Privacy: Ethics and Legalities of Data Collection, Usage, and Storage." Proceedings of the 13th International Conference on Educational Data Mining (EDM 2020). Retrieved September 22, 2020, from https://educationaldatamining.org/ edm2020/proceedings/.

Willis, J. E., Slade, S., \& Prinsloo, P. (2016). Ethical oversight of student data in learning analytics: A typology derived from a cross-continental, cross-institutional perspective. Educational Technology Research and Development, 64, 881-901. https://doi.org/10.1007/s11423-016-9463-4.

Publisher's Note Springer Nature remains neutral with regard to jurisdictional claims in published maps and institutional affiliations. 
Gloria Natividad Beltrán del Río Dr. Gloria Natividad Beltrán del Río is a Professor at the Tecnológico Nacional de México, Instituto Tecnológico de Saltillo, México. She earned her M.C. in Applied Technology, Training and Development and her Ph.D. in Applied Technology and Performance Improvement from the University of North Texas. Her dissertation captured the trends in a number of research streams within the discipline of educational technology and identified the point in time when massive changes took place, and was eventually transformed into a book: An Analysis of Two Decades of Educational Technology Publications: Who, What, and Where, co-authored by Drs. J. Michael Spector and Nicholas Evangelopoulos. She began serving ETR\&D Educational Technology, Research and Development journal, as an editorial assistant and later as an assistant editor for the Development Section. She serves as a Co-Editor for the online Major Reference Work (MRW) co-sponsored by AECT and Springer entitled Learning, Design, and Technology: An International Compendium of Theory, Research, Practice and Policy; for the Literature Reviews and Systematic Reviews of Research Section. 